

Journal of Fish Biology (2007) 71, 1-9

doi:10.1111/j.1095-8649.2007.01510.x, available online at http://www.blackwell-synergy.com

\title{
Fungi isolated from cultured eggs, alevins and broodfish of brown trout in a hatchery affected by saprolegniosis
}

\author{
J. M. Fregeneda-Grandes, F. Rodríguez-Cadenas \\ And J. M. Aller-Gancedo* \\ Departamento de Sanidad Animal, Universidad de León, Campus de Vegazana s/n, \\ 24071 León, Spain
}

(Received 21 July 2006, Accepted 5 March 2006)

\begin{abstract}
The aquatic fungi cultured from eggs, alevins and broodfish of brown trout Salmo trutta belonged to the genus Saprolegnia and were identified as S. diclina, S. australis, S. ferax, $S$. furcata, S. hypogyna, S. unispora and S. parasitica. The species obtained from infected eggs and alevins were different to those from infected fish. Several Saprolegnia species were isolated from eggs and alevins, whereas all the isolates obtained from broodfish were the pathogenic S. parasitica.

(C) 2007 The Authors

Journal compilation (C) 2007 The Fisheries Society of the British Isles
\end{abstract}

Key words: aquaculture; diseases; salmonids; Saprolegnia; S. diclina; S. parasitica.

\section{INTRODUCTION}

Fungal infection of fish eggs is a major economic problem with many freshwater species, especially salmonids in hatcheries (Neish \& Hughes, 1980; Srivastava, 1987; Willoughby, 1994). Members of the family Saprolegniaceae (Oomycetes), mainly the genus Saprolegnia, are responsible and they can also affect adult fishes (Scott \& O’Bier, 1962; Czeczuga \& Woronowicz, 1993). Many species of fungi have been isolated from salmonid eggs (Czeczuga \& Muszynska, 1996; Kitancharoen et al., 1997; Hussein et al., 2001) a probable reflection of the diversity of fungi found in the aquatic environment. In contrast, studies on adult salmonids with cutaneous lesions show that one type of Saprolegnia predominates, having characteristics such as long bundles of hairs in the secondary cysts and indirect germination (septate secondary cyst germ tubes). These features differentiate it from other Saprolegnia species (Pickering \& Willoughby, 1982; Willoughby, 1985; Aller-Gancedo \& Fernández-Díez, 1987; Beakes et al., 1994). Depending on the taxonomic criteria used, these salmonid-pathogenic

\footnotetext{
*Author to whom correspondence should be addressed. Tel.: +34 987291 303; fax: +34 987291 304; email: jmallg@unileon.es 
Saprolegnia isolates have been identified as S. parasitica, S. diclina, S. diclina type 1, S. diclina-S. parasitica complex, Saprolegnia sp. and 'salmonid Saprolegnia'. Some of these names, however, have been used for saprophytic isolates of Saprolegnia, which has lead to considerable taxonomic confusion. Since the epizootic of saprolegniosis that occurred in the 1980s, causing a high mortality rate among wild brown trout Salmo trutta L. in various rivers in the Province of Leon (north-west Spain), these salmonid Saprolegnia isolates have been the only pathogen isolated from lesions of fish (Aller-Gancedo \& Fernández-Díez, 1987; Fregeneda-Grandes et al., 2000). Beakes et al. (1994) and DiéguezUribeondo et al. (2007) recommend the name $S$. parasitica to designate these salmonid Saprolegnia isolates.

There have been no studies of the aquatic fungi developing on brown trout eggs in Spain. Hence, the aim of this study was to identify the aquatic fungi, limited to the Oomycetes, that colonize brown trout eggs and alevins in a hatchery and to compare the results with those obtained from broodfish suffering saprolegniosis in the same hatchery.

\section{MATERIALS AND METHODS}

The study was based on a brown trout hatchery at Vegas del Condado in the Province of Leon, north-west Spain, owned by the Castile and Leon Regional Government (Junta de Castilla y León). Eggs were incubated in trays inside troughs with $c .7000$ eggs per tray distributed as a monolayer. Continuously flowing well water (at $7-9^{\circ} \mathrm{C}$ ) was used throughout egg incubation at a rate of $c .151 \mathrm{~min}^{-1}$. During incubation, the eggs received routine prophylactic treatments with Proxitane ${ }^{\circledR} 0510$ (Solvay Interox S.A., Barcelona, Spain) or Pyceze ${ }^{\circledR}$ (Novartis Animal Vaccines Ltd, Braintree, U.K.).

Ninety-two samples were obtained: 74 from eggs, nine from alevins (yolk-sac fry) and nine from broodfish, all of them bearing macroscopic fungal colonization. To isolate the fungi, eggs coated with fungal mycelia (Fig. 1) were removed from trays and taken to the laboratory in $28 \mathrm{ml}$ glass bottles filled with sterile distilled water (one egg per bottle). Here the samples were washed several times with sterile distilled water, then egg membranes with fungal mycelia were separated, washed again and placed in plastic Petri dishes with $20 \mathrm{ml}$ of paper-filtered and autoclave-sterilized river water (SRW).

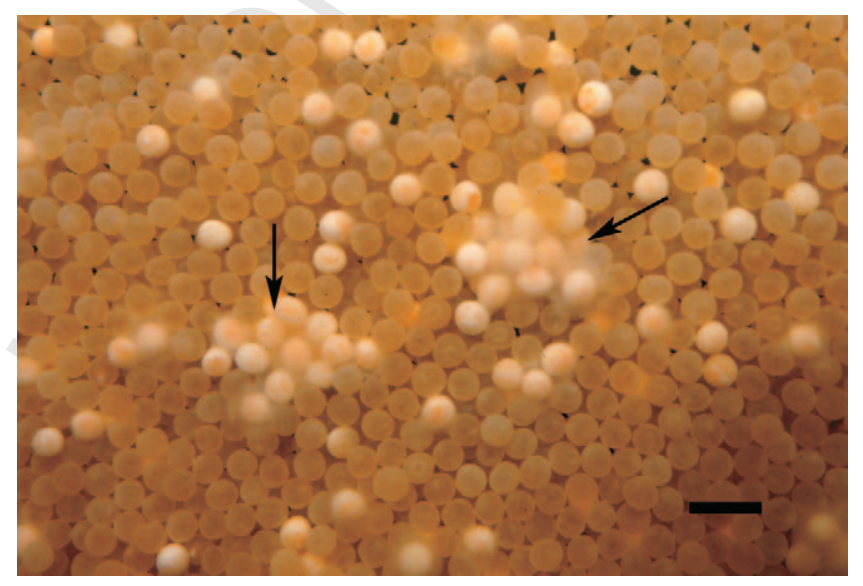

FIG. 1. Brown trout eggs colonized with Saprolegnia $(\rightarrow)$ incubated in trays in a hatchery. Scale bar $=10 \mathrm{~mm}$. 
The dishes were incubated for $24 \mathrm{~h}$ at $20^{\circ} \mathrm{C}$ and examined stereomicroscopically for the morphology of the colonies, to determine if one or more types of fungi were growing concurrently. A sample of the mycelium was seeded onto glucose-peptone agar (Willoughby, 1994) with chloramphenicol $\left(200 \mu \mathrm{g} \mathrm{ml}^{-1}\right)$ and bacteria-free cultures were obtained by successive passages on this medium. Isolation from broodfish with cutaneous lesions (Fig. 2) and infected alevins (Fig. 3) was carried out on the same medium using a small portion of mycelium from the lesions, previously washed in sterile distilled water.

For identification, the isolates were cultivated on glucose-peptone agar with hemp seeds Cannabis sativa L. Subsequently, the fungi were cultivated in Petri dishes with SRW (one colonized seed per dish) and incubated in darkness at 20 or $7^{\circ} \mathrm{C}$ with at least two dishes for each temperature. Cultures were examined periodically for 2 months to monitor the development of sexual structures. The fungi were identified from classical morphological features following Coker (1923), Seymour (1970) and Johnson et al. (2002). Saprolegnia parasitica was identified from bundles of long hairs on secondary cysts and their indirect germination (Willoughby, 1985; Beakes et al., 1994; Diéguez-Uribeondo et al., 2007).

\section{RESULTS}

All the isolates belonged to genus Saprolegnia. The 74 isolates obtained from colonized eggs were identified as: S. diclina (38 isolates), S. australis (11 isolates), S. ferax (four isolates), S. furcata (four isolates), S. hypogyna (three isolates), S. parasitica (two isolates) and $S$. unispora (one isolate). The remaining 11 isolates from eggs could not be identified to species because they did not develop sexually, so they were designated Saprolegnia spp. The nine isolates obtained from alevins were identified as: $S$. diclina (four isolates), S. ferax (two isolates), $S$. parasitica (two isolates) and $S$. australis (one isolate). The nine isolates obtained from broodfish with saprolegniosis were identified as $S$. parasitica (Table I).

The six sexual Saprolegnia species identified had the morphological characteristics of the oogonia, oospores and antheridial branches described for their respective species (Table II and Fig. 4). The $S$. parasitica isolates, in contrast



FIG. 2. Four year-old farmed male brown trout broodfish with skin lesions $(\rightarrow)$ caused by Saprolegnia parasitica. Scale bar $=50 \mathrm{~mm}$. 


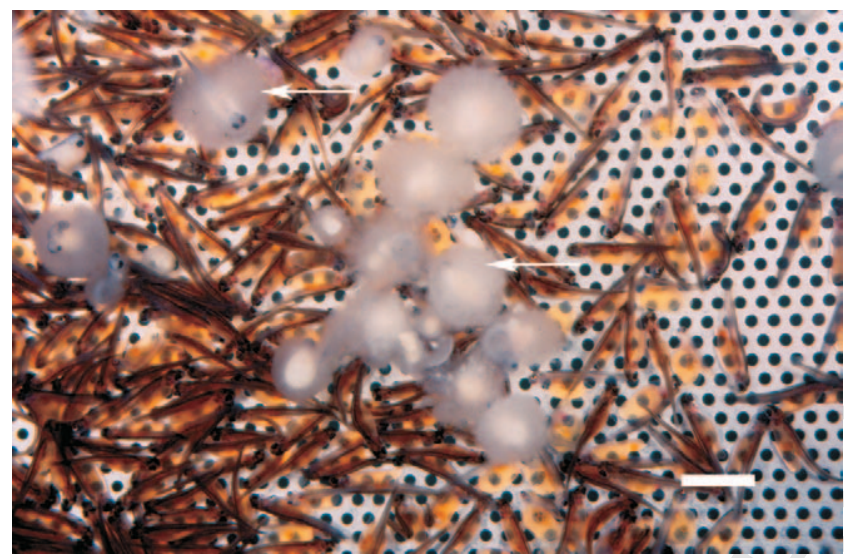

Fig. 3. Seven days-old brown trout alevins colonized with Saprolegnia $(\rightarrow)$ incubated in trays in a hatchery. Scale bar $=10 \mathrm{~mm}$.

with these six species and the asexual Saprolegnia sp. isolates, had secondary cysts with bundles of long hairs and indirect germination that were visible with phase-contrast microscopy. Of the 13 isolates identified as $S$. parasitica (two from eggs, two from alevins and nine from broodfish), 12 were asexual isolates lacking oogonia (Saprolegnia sp. according to classical taxonomic criteria), even after incubation for 80 days at $7^{\circ} \mathrm{C}$. One isolate had oogonia (obtained from a single, infected alevin) which developed at $7^{\circ} \mathrm{C}$ after 30 days of incubation but they were very scarce and generally grouped together in the same zone of the colony. The morphological characteristics of the sexual structures (oogonia,

TABLE I. Saprolegnia spp. isolated from eggs, alevins and broodfish of brown trout in a hatchery suffering from saprolegniosis

\begin{tabular}{lcl}
\hline Source & Number of isolates & Identification $($ Number of isolates $/ \%)$ \\
\hline Eggs & 74 & S. diclina $(38 / 51 \cdot 4)$ \\
& & S. australis $(11 / 14 \cdot 9)$ \\
& S. ferax $(4 / 5 \cdot 4)$ \\
& S. furcata $(4 / 5 \cdot 4)$ \\
& S. hypogyna $(3 / 4 \cdot 1)$ \\
& S. parasitica $(2 / 2 \cdot 7)^{*}$ \\
& S. unispora $(1 / 1 \cdot 4)$ \\
& Saprolegnia $\operatorname{sp.}(11 / 14 \cdot 9)^{*}$ \\
Alevins & S. diclina $(4 / 44 \cdot 4)$ \\
& & S. ferax $(2 / 22 \cdot 2)$ \\
& & S. parasitica $(2 / 22 \cdot 2)^{\dagger}$ \\
& 9 & S. australis $(1 / 11 \cdot 1)$ \\
Broodfish & & S. parasitica $(9 / 100)^{*}$ \\
Total & & \\
\hline
\end{tabular}

*Asexual.

${ }^{\dagger}$ One asexual and one with oogonia. 
FUNGI ON BROWN TROUT EGGS AND FISH

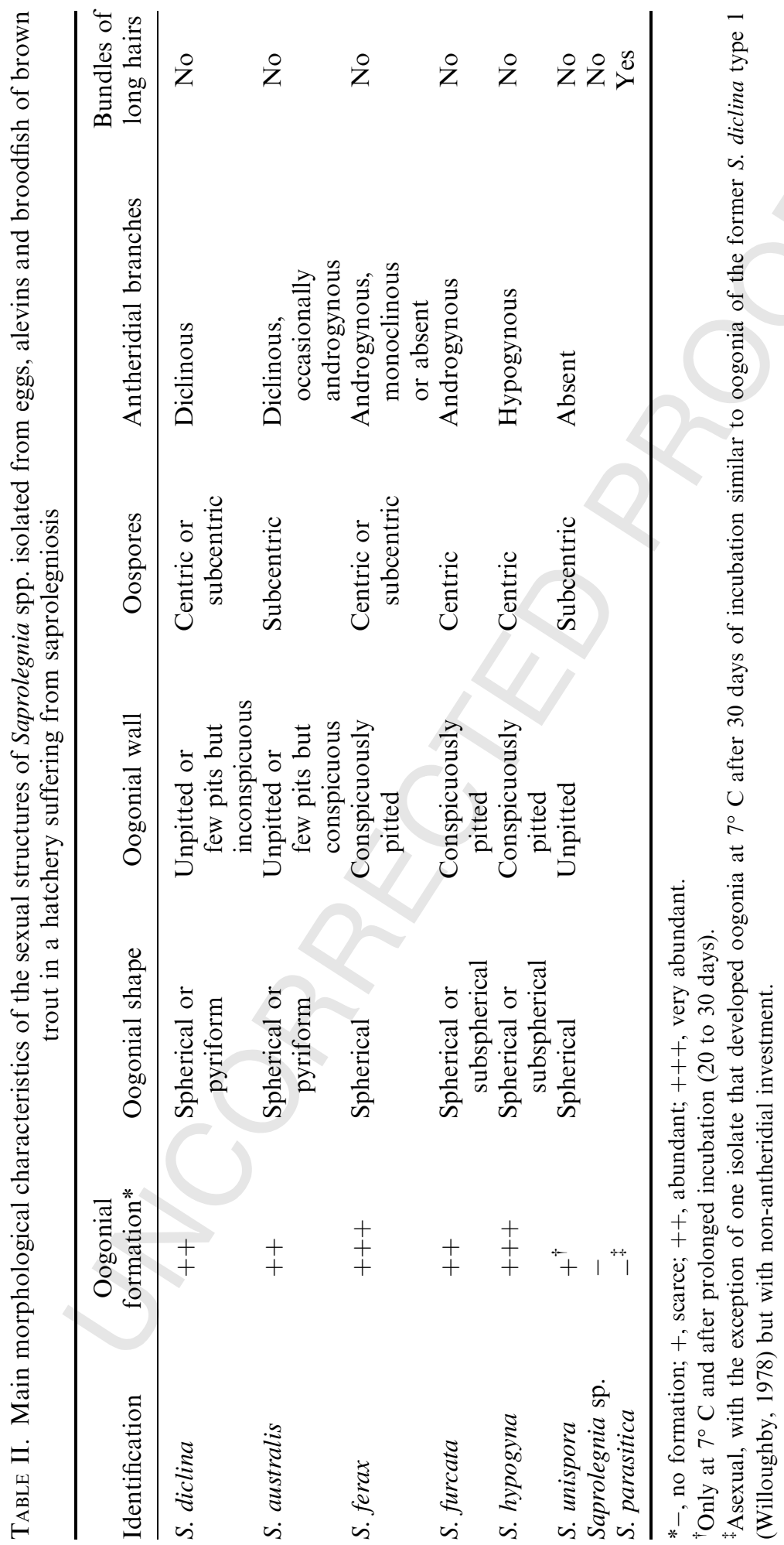



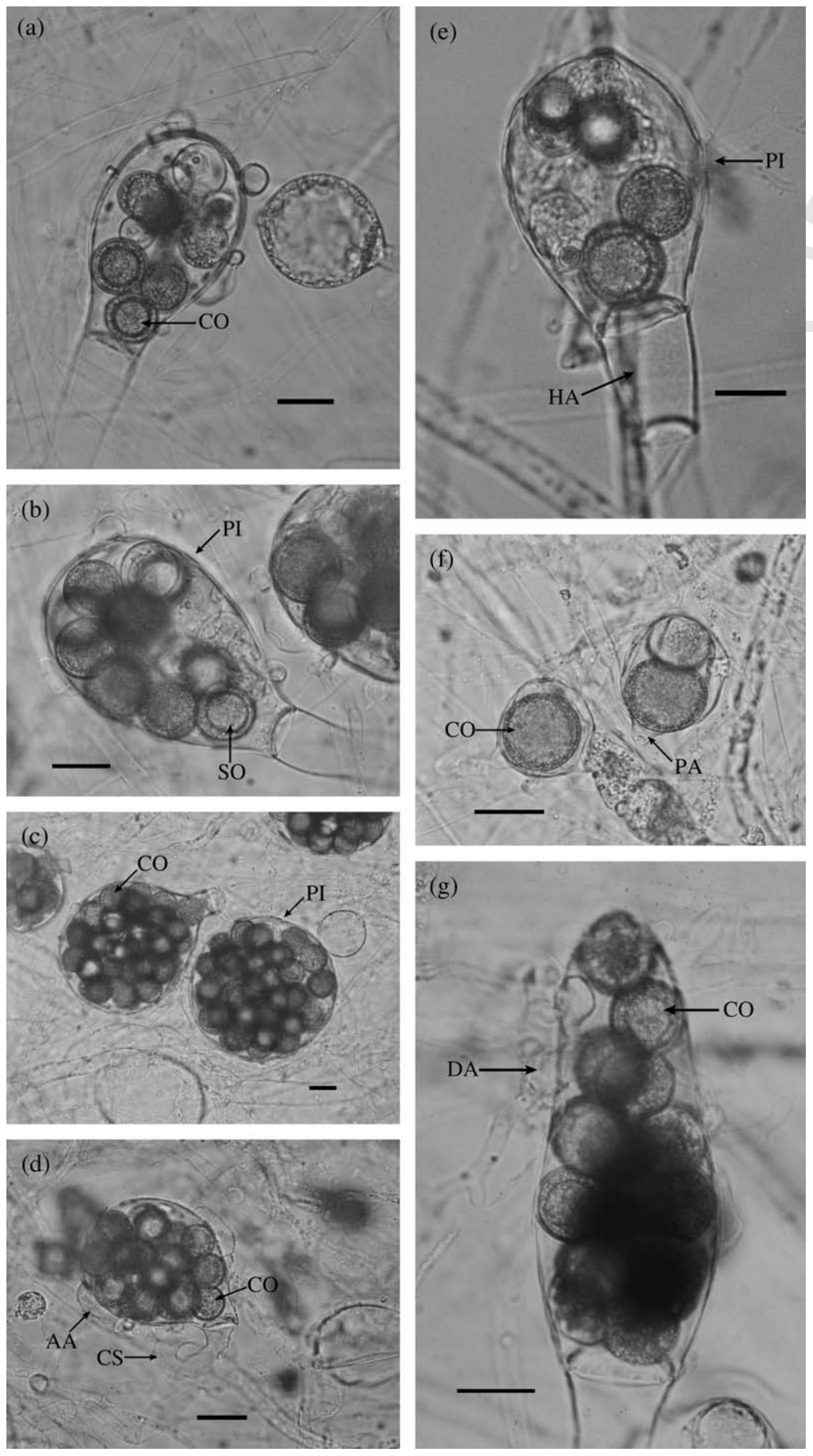
oospores and antheridia) of this isolate were very similar to the former S. diclina type 1 described by Willoughby (1978) but with non-antheridial invested oogonia (Fig. 4).

\section{DISCUSSION}

The aquatic fungi able to colonize fish eggs, particularly those of salmonids, are mostly species of Achlya, Aphanomyces, Saprolegnia, or less often, Dictyuchus, Leptolegnia and Thraustotheca, all belonging to the Saprolegniales. Species of the genera Leptomitus and Pythium are the commonest within the orders Leptomitales and Pythiales, respectively (Czeczuga \& Woronowicz, 1993; Czeczuga et al., 1996, 2005; Kitancharoen et al., 1997; Hussein et al., 2001). These data suggest that species of Saprolegnia are the principal microorganisms associated with fungal colonization of salmonid eggs. In the present study, all the isolates obtained from colonized brown trout eggs were Saprolegnia. On two occasions, however, fungi growing directly on egg membranes, were identified as Leptolegnia spp., but were mixed with Saprolegnia spp. Attempts to grow them as pure cultures, produced only Saprolegnia spp. Among the species of Saprolegnia, S. diclina was the most frequent, followed by $S$. australis, although 11 non-sexual isolates remained unidentified to species. Similar results were obtained from alevins. All isolates belonged to the genus Saprolegnia and the most frequent species was S. diclina. A statistical comparison between the isolates obtained from eggs and those from alevins was not possible because of the small number of isolates of some species. Routine prophylaxis with antifungals are used during the incubation of eggs in hatcheries. Such treatment was in use at the fish farm where the study was undertaken. Hence, the results reflect the situation in a fish farm under normal production conditions. Kitancharoen et al. (1997) investigated the aquatic fungi developing on the eggs of five salmonid species at six fishery stations in Japan and similarly found that $S$. diclina was commonest. In contrast, Czeczuga et al. (2005) studying the eggs of sea trout (anadromous brown trout) in Poland found the commonest species were Achlya polyandra, S. ferax, $S$. parasitica and Leptomitus lacteus. These differences might be explained because fungal colonization normally originates on dead eggs (Smith et al., 1985; Kitancharoen \& Hatai, 1996) and all these fungi are saprobes in aquatic systems. Thus, the different species found on fish eggs at different locations could be a reflection of the diversity of aquatic fungi present, depending on the physical and chemical conditions of the water.

FIG. 4. Main morphological characteristics of the sexual structures of Saprolegnia spp. isolated from eggs, alevins and broodfish of brown trout in a hatchery with saprolegniosis. (a) Saprolegnia diclina: pyriform unpitted oogonium with centric oospores. (b) Saprolegnia australis: pyriform oogonium with pits and subcentric oopores. (c) Saprolegnia ferax: spherical pitted oogonia with centric oospores and no antheridial branches. (d) Saprolegnia furcata: subspherical oogonium with coiled stalk, centric oospores and androgynous antheridial branches. (e) Saprolegnia hypogyna: subspherical pitted oogonium with hypogynous antheridial cell. (f) Saprolegnia unispora: spherical papillate oogonia with centric oospores and no antheridial branches. (g) Saprolegnia parasitica: elongated oogonium with centric oospores and diclinous antheridial branches. CO, centric oospore; SO, subcentric oospore; PI, pitting; CS, coiled stalk; PA, papillae; AA, androgynous antheridium; HA, hypogynous antheridium; DA, diclinous antheridium. Scale bars $=25 \mu \mathrm{m}$. 
In contrast to the results obtained from eggs, when studies were carried out on live adult salmonids with cutaneous lesions from extensive geographical areas, normally only one type of Saprolegnia isolate was found (Neish, 1977; Willoughby, 1978; Aller-Gancedo \& Fernández-Díez, 1987; Hatai et al., 1990). In fact, a number of authors have named this type $S$. parasitica, distinguished from the description of the species given by Kanouse (1932). These isolates have certain characteristics, such as long bundles of hairs in the secondary cysts, indirect germination in low nutrient media and internal transcribed spacer (ITS) sequences that allow them to be differentiated from other Saprolegnia species (Diéguez-Uribeondo et al., 2007). They frequently do not develop sexual structures under laboratory conditions, however, which prevents species identification from classical morphological criteria. These pathogenic isolates of salmonids are rarely found on infected eggs (Kitancharoen et al., 1997). The results of present study agree with these observations, since only two such isolates were obtained from infected eggs (out of 74 isolates), whereas all the isolates from broodfish were identified as S. parasitica. On the other hand, these results contradict those found by Czeczuga et al. (2005), who were able to isolate $S$. parasitica from the eggs of all 42 sea trout females investigated on three fish farms in Poland. It may be that these authors are using the name S. parasitica in the original sense assigned by Coker (1923), meaning any asexual Saprolegnia isolate obtained from fishes or fish eggs, or by Kanouse (1932), and not in the sense given by Beakes et al. (1994) and Diéguez-Uribeondo et al., 2007. In the present study, the 11 asexual isolates and the two isolates of $S$. parasitica obtained from colonized eggs could be identified as $S$. parasitica in accordance with Coker's concept, therefore this would be the second commonest species found. One conclusion of the present study was that eggs and alevins of brown trout were infected or colonized after death by various Saprolegnia saprophytic species, whereas trout (salmonids) were infected by pathogenic $S$. parasitica isolates.

This study was carried out in connection with research projects AGL2002-00505 of the Spanish Ministry of Education and Science (Ministerio de Educación y Ciencia) and 2004/79 of the University of Leon (Spain) and Novartis Animal Vaccines Ltd (U.K.). F.R.-C. was funded by project AGL2002-00505. The authors wish to express their thanks for the facilities provided by the Local Environmental Service for Leon of the Regional Government of Castile and Leon (Servicio Territorial de Medio Ambiente de León, Junta de Castilla y León) to enable completion of this study at their hatchery in Vegas del Condado, in Leon Province in Spain.

\section{References}

Aller-Gancedo, J. M. \& Fernández-Díez, M. (1987). Saprolegniosis in brown trout (Salmo trutta) in the rivers of León (Spain). Medicina Veterinaria 4, 181-184.

Beakes, G. W., Wood, S. E. \& Burr, A. W. (1994). Features which characterize Saprolegnia isolates from salmon fish lesions - a review. In Salmon Saprolegniasis (Mueller, J., ed.), pp. 52-66. Porland, OR: US Department of Energy, Bonneville Power Administration, Division of Fish and Wildlife.

Coker, W. C. (1923). The Saprolegniaceae, with Notes on Other Water Molds. Chapel Hill, NC: The University of North Carolina Press [reprint by Cramer, J. (1979), Bibliotheca Mycologica, band 20, Vaduz]. 
Czeczuga, B. \& Muszynska, E. (1996). Growth of zoosporic fungi on the eggs of North Pacific salmon of the genus Oncorhynchus in laboratory conditions. Acta Ichthyologica et Piscatoria 26, 25-37.

Czeczuga, B. \& Woronowicz, L. (1993). Aquatic fungi developing on the eggs of certain freshwater fish species and their environments. Acta Ichthyologica et Piscatoria 23, 39-57.

Czeczuga, B., Muszynska, E. \& Tryggvadottir, S. V. (1996). Aquatic fungi growing on the eggs of nine salmonid species of the genus Hucho, Salmo and Salvelinus. Acta Ichthyologica et Piscatoria 26, 113-124.

Czeczuga, B., Bartel, R., Kiziewicz, B., Godlewska, A. \& Muszynska, E. (2005). Zoosporic fungi growing on the eggs of sea trout (Salmo trutta m. trutta L.) in river water of varied trophicity. Polish Journal of Environmental Studies 14, 295-303.

Diéguez-Uribeondo, J., Fregeneda-Grandes, J. M., Cerenius, L., Pérez-Iniesta, E., AllerGancedo, J. M., Tellería, M. T., Söderhäll, K. \& Martín, M. P. (2007). Re-evaluation of the enigmatic species complex Saprolegnia diclina-S. parasitica based on morphological, physiological and molecular data. Fungal Genetics and Biology (in press).

Fregeneda-Grandes, J. M., Fernández-Díez, M. \& Aller-Gancedo, J. M. (2000). Ultrastructural analysis of Saprolegnia secondary zoospore cyst ornamentation from infected wild brown trout, Salmo trutta L., and river water indicates two distinct morphotypes amongst long-spined isolates. Journal of Fish Diseases 23, 147-160. doi: 10.1046/j.1365-2761.2000.00239.x; Erratum. Journal of Fish Diseases 26, 313. doi: $10.1046 / j .1365-2761.2003 .00265 . x$

Hatai, K., Willoughby, L. G. \& Beakes, G. W. (1990). Some characteristics of Saprolegnia obtained from fish hatcheries in Japan. Mycological Research 94, 182-190.

Hussein, M. M. A., Hatai, K. \& Nomura, T. (2001). Saprolegniosis in salmonids and their eggs in Japan. Journal of Wildlife Diseases 37, 204-207.

Kanouse, B. B. (1932). A physiological and morphological study of Saprolegnia parasitica. Mycologia 24, 431-452.

Kitancharoen, N. \& Hatai, K. (1996). Experimental infection of Saprolegnia spp. in rainbow trout eggs. Fish Pathology 31, 49-50.

Kitancharoen, N., Hatai, K. \& Yamamoto, A. (1997). Aquatic fungi developing on eggs of salmonids. Journal of Aquatic Animal Health 9, 314-316.

Neish, G. A. (1977). Observations on Saprolegniasis of adult Sockeye Salmon, Oncorhynchus nerka (Walbaum). Journal of Fish Biology 10, 513-522. doi: 10.1111/j. 1095-8649.1977.tb04084.x

Neish, G. A. \& Hughes, G. C. (1980). Fungal Diseases of Fishes. Neptune, NJ: T.F.H. Publications.

Pickering, A. D. \& Willoughby, L. G. (1982). Saprolegnia infections of salmonid fish. Freshwater Biological Association Annual Report 50, 38-48.

Scott, W. W. \& O'Bier, A. H. (1962). Aquatic fungi associated with diseased fish and fish eggs. Progressive Fish-Culturist 24, 3-15.

Seymour, R. L. (1970). The genus Saprolegnia. Nova Hedwigia 19, 1-124.

Smith, S. N., Armstrong, R. A., Springate, J. \& Barker, G. (1985). Infection and colonization of trout eggs by Saprolegniaceae. Transactions of the British Mycological Society 85, 719-723.

Srivastava, R. C. (1987). Fish Mycopathology. New Delhi: Today \& Tomorrow's Printers and Publishers.

Willoughby, L. G. (1978). Saprolegnias of salmonid fish in Windermere: a critical analysis. Journal of Fish Diseases 1, 51-67. doi: 10.1111/j.1365-2761.1978.tb00005.x

Willoughby, L. G. (1985). Rapid preliminary screening of Saprolegnia on fish. Journal of Fish Diseases 8, 473-476. doi: 10.1111/j.1365-2761.1985.tb01282.x

Willoughby, L. G. (1994). Fungi and Fish Diseases. Stirling: Pisces Press.

\section{Electronic Reference}

Johnson, T. W. Jr, Seymour, R. L. \& Padgett, D. E. (2002). Biology and Systematics of the Saprolegniaceae. Available at http://www.ilumina-dlib.org and http://www.uncw. edu/people/padgett 


\section{Author Query Form}

\section{Journal: Journal of Fish Biology}

\section{Article : jfb_1510}

Dear Author,

During the copy-editing of your paper, the following queries arose. Please respond to these by marking up your proofs with the necessary changes/additions. Please write your answers on the query sheet if there is insufficient space on the page proofs. Please write clearly and follow the conventions shown on the attached corrections sheet. If returning the proof by fax do not write too close to the paper's edge. Please remember that illegible mark-ups may delay publication.

Many thanks for your assistance.

Query
No.

$1 \quad$ Please update reference 'Diéguez-Uribeondo et al. (2007)'. 


\section{Please correct and return this set}

Please use the proof correction marks shown below for all alterations and corrections. If you wish to return your proof by fax you should ensure that all amendments are written clearly in dark ink and are made well within the page margins.

\begin{tabular}{|c|c|c|}
\hline Instruction to printer & Textual mark & Marginal mark \\
\hline Leave unchanged & ... under matter to remain & ( ) \\
\hline $\begin{array}{l}\text { Insert in text the matter } \\
\text { indicated in the margin }\end{array}$ & $h$ & $\begin{array}{l}\text { New matter followed by } \\
h \text { or } h \otimes\end{array}$ \\
\hline Delete & $\begin{array}{l}\text { I through single character, rule or underline } \\
\text { or }\end{array}$ & $\sigma$ or $\sigma(x)$ \\
\hline $\begin{array}{l}\text { Substitute character or } \\
\text { substitute part of one or } \\
\text { more word(s) }\end{array}$ & I through letter or & $\begin{array}{l}\text { new character / or } \\
\text { new characters / }\end{array}$ \\
\hline Change to italics & — under matter to be changed & $\leftarrow$ \\
\hline Change to capitals & $\equiv$ under matter to be changed & $\equiv$ \\
\hline Change to small capitals & $=$ under matter to be changed & $=$ \\
\hline Change to bold type & $\sim$ under matter to be changed & $\sim$ \\
\hline Change to bold italic & $\bar{\sim}$ under matter to be changed & $\tilde{\omega}$ \\
\hline Change to lower case & Encircle matter to be changed & $\Rightarrow$ \\
\hline Change italic to upright type & (As above) & \\
\hline Change bold to non-bold type & (As above) & \\
\hline Insert 'superior' character & $\begin{array}{l}/ \text { through character or } \\
K \text { where required }\end{array}$ & $\begin{array}{l}y^{\prime} \text { or } y \\
\text { under character } \\
\text { e.g. } y^{2} \text { or } y^{2}\end{array}$ \\
\hline Insert 'inferior' character & (As above) & $\begin{array}{l}\lambda \\
\text { over character } \\
\text { e.g. } \hat{\Sigma}\end{array}$ \\
\hline Insert full stop & (As above) & $\odot$ \\
\hline Insert comma & (As above) & , \\
\hline Insert single quotation marks & (As above) & $\begin{array}{l}\dot{y} \text { or } \dot{x} \text { and/or } \\
\dot{y} \text { or } \dot{y}\end{array}$ \\
\hline Insert double quotation marks & (As above) & $\begin{array}{l}\ddot{y} \text { or } \ddot{x} \text { and/or } \\
\ddot{y} \text { or } \ddot{x}\end{array}$ \\
\hline Insert hyphen & (As above) & 1 \\
\hline Start new paragraph & 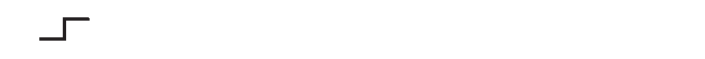 & 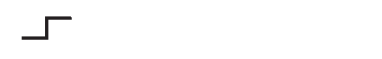 \\
\hline No new paragraph & $\infty$ & $\omega$ \\
\hline Transpose & $\sqcup$ & $\sqcup$ \\
\hline Close up & linking $\bigcirc$ characters & \\
\hline $\begin{array}{l}\text { Insert or substitute space } \\
\text { between characters or words }\end{array}$ & $\begin{array}{l}\text { I through character or } \\
K \text { where required }\end{array}$ & \\
\hline $\begin{array}{l}\text { Reduce space between } \\
\text { characters or words }\end{array}$ & $\begin{array}{l}\text { between characters or } \\
\text { words affected }\end{array}$ & $\uparrow$ \\
\hline
\end{tabular}

